\title{
Neonatal Thyrotoxicosis
}

National Cancer Institute

\section{Source}

National Cancer Institute. Neonatal Thyrotoxicosis. NCI Thesaurus. Code C114906.

A hypermetabolic syndrome characterized by tachycardia, palpitations, tremor, weight loss, and moist skin that is caused by the elevation of thyroid hormone levels in the serum of the newborn infant or thyroid-axis receptor activation, most commonly due to transplacental passage of thyroid stimulating globulins. 